\title{
Strength Investigation of an Upholstered Furniture Frame with Side Plates of PB, OSB and PLY by Finite Element Method
}

\section{Ispitivanje čvrstoće okvira ojastučenog namještaja s bočnim stranicama od drvnih ploča metodom konačnih elemenata}

\author{
Original scientific paper • Izvorni znanstveni rad \\ Received-prispjelo: 21. 3. 2019. \\ Accepted-prihvaćeno: 28. 4. 2020. \\ UDK: $630 * 824.52 ; 630 * 863.1$ \\ https://doi.org/10.5552/drvind.2020.1921
}

(C) 2020 by the author(s).

Licensee Faculty of Forestry, University of Zagreb.
This article is an open access article distributed
under the terms and conditions of the
Creative Commons Attribution (CC BY 4.0) license.

\begin{abstract}
Comparative analysis of the strength characteristics of one-seat upholstered furniture frame with rails of Pinus Sylvestris L. and side plates of PB, OSB and PLY boards was carried out. $3 D$ geometric model of the upholstered furniture frame was created by Autodesk Inventor Pro ${ }^{\circledR}$. Linear static analyses were carried out by the method of finite elements (FEM) simulating light-service loading. The orthotropic material characteristics of the used materials were considered in the analyses. Two variants of corner joints in the frame (model A - staples and PVAc; model B - staples, PVAc and strengthening elements under the rail of the seat) were considered. The laboratory established coefficients of rotational stiffness of used staple corner joints in the skeleton were considered in finite element analysis (FEA). As result, the distribution of the maximum and minimum principal stresses in the $3 D$ model of upholstered furniture frame side plates were derived and analysed. The worst failure indexes according to Tsai-Wu failure criteria were calculated at heavy-service load. The study provided database of strength values that can help in the engineering of upholstered furniture frames with side plates of PB, OSB and PLY.
\end{abstract}

Key words: strength; upholstered furniture frame; particleboard; oriented strand board; plywood; CAE/FEM.

SAŽETAK • Provedena je usporedba svojstava čvrstoće okvira ojastučenog naslonjača s poveznicima od borovine (Pinus Sylvestris L.) is bočnim stranicama od drvnih ploča (iverice, OSB ploče i furnirske ploče). Za potrebe ispitivanja uz pomoć programa Autodesk Inventor Pro ${ }^{\circledR}$ izrađen je $3 D$ geometrijski model okvira ojastučenog namještaja. Linearne statičke analize provedene su metodom konačnih elemenata (FEM) uz simuliranje malog opterećenja. $U$ analizama su uzeta u obzir svojstva ortotropnog materijala. Promatrane su dvije varijante kutnih spojeva okvira (model A - sponke i PVAc; model B - sponke, PVAc i pojačanja poveznika ispod sjedala). Analizom konačnih elemenata (FEA) razmatrani su laboratorijski utvrđeni koeficijenti rotacijske krutosti sponki upotrijebljenih za kutne spojeve okvira. Time je dobivena i analizirana raspodjela najvećih i najmanjih glavnih naprezanja u 3D modelu bočnih stranica potkonstrukcije ojastučenog namještaja. Najlošiji indeksi loma prema Tsai-Wu kriterijima loma izračunani su pri velikim opterećenjima. Kao rezultat istraživanja dobivena je baza podataka o vrijednostima čvrstoće koja može pomoći u projektiranju okvira ojastučenog namještaja s bočnim stranicama od iverica, OSB ploča i furnirskih ploča.

Ključne riječi: čvrstoća; okvir ojastučenog namještaja; iverica; OSB ploča; furnirska ploča; CAE/FEM

\footnotetext{
${ }^{1}$ Authors are assistant professors at Faculty of Forest Industry, University of Forestry, Sofia, Bulgaria.
} 


\section{INTRODUCTION}

\section{UVOD}

The frame of upholstered furniture is usually made of wood and/or wood-based products. The choice of the materials from which the structure elements in the furniture frame construction are made and their thickness is essential both for the economy of the structure and for the strength behaviour during operation. Strength characteristics of upholstered furniture frames are very important to ensure optimal design of upholstered furniture.

There is a limited number of references concerning the strength behaviour of upholstered furniture frames, especially of frames with side plates of particleboard (PB), oriented strand board (OSB) and plywood (PLY).

Smardzewski (2001) found an optimal solution for the construction of a supporting structure in a single-seat armchair made of wood and chipboard joined with staples using Algor $^{\circledR}$ computer program. Material optimization of construction was performed assuring optimal strength parameters, but the materials were considered as isotropic. He recommended the sides of the construction should be produced of a $19 \mathrm{~mm}$ thick chipboard in order to comply with safety requirements. Lately Smardzewski et al. (2009) have carried out laboratory and numerical investigations of two-person sofa frame with side elements of PB and beam elements of pine and beech wood (joints with staples and PVAc glue) taking account of orthotropic nature of used materials in the finite element analysis (FEA) with Algor ${ }^{\circledR}$. They have proposed smaller cross section dimensions and side thickness of the construction elements that would result in consumption reduction of beech wood by $36 \%$ and that of PB by $25 \%$ without significant change of the operational safety, rigidity and strength.

Wang (2007) investigated a three-seat sofa frame made of $18 \mathrm{~mm}$ thick OSB plates. She created 3D models by beam finite elements with software SAP 2000 of three constructions of a sofa frame with rigid and semirigid connections and two types of connectors: screws and metal plates; staples and metal plates. Nonlinear static analysis was performed simulating light-, medium- and heavy-service loads. Wang has established the most appropriate configuration of the sofa frame of OSB and concluded that the type of connectors does not change the strength remarkably.

Kasal (2006) investigated the strength properties of glued dowel joined armchair frame constructed of solid wood or wood based composite materials, $18 \mathrm{~mm}$ thick (PLY, MDF and OSB) using the finite beam elements by CAE. Considering wood materials as isotropic, he established that significant differences were not found in mechanical behaviour properties, but that the OSB had the lowest load bearing capacity. He has established that the failure of OSB sofa frame is the pullout of dowels from the member with some core wood particles attached to the dowel, while some splits occur at the edge of the butt members in the sofa frames. In the frame constructed of pine wood (PW), delamination occurs in the layers of the plywood but such a construction has close strength values to the construction of beech and can be preferred to the solid beech and solid pine due to its many technical and economic advantages.

Using the simplified methods of structural analysis, Erdil et al. (2008) investigated the behaviour of 3 -seat upholstered furniture frames constructed of 3/4 inch thick OSB, PLY (Douglas-fir and sweet gum), and yellow birch dowels joining elements and aliphatic resin glue (PVA). They have concluded that these materials may be used in construction of upholstered furniture frames to meet specific design loads.

Staneva et al. (2018a, b, c) made preliminary investigations of upholstered frame with side plates of PB (2018a), OSB (2018b) and PLY (2018c) at lightservice load by FEM and have established the distribution of the principal stresses.

The object of this study is to carry out a comparative FEA of static strength of an upholstered furniture frame with side plates of PB, OSB and PLY furniture boards and joints with staple and PVAc glue with a CAE system.

\section{METHODS - 3D FEM MODELLING AND ANALISYS}

\section{METODE - 3D FEM MODELIRANJE I ANALIZA}

3D discrete model of one-seat upholstered furniture side frame with length $600 \mathrm{~mm}$, width $725 \mathrm{~mm}$ and height $650 \mathrm{~mm}$ (Figure 1a) was developed with Autodesk Inventor Pro ${ }^{\circledR}$ and marked model $A$ - Figure $1 \mathrm{~b}$. The cross section of used rails was $25 \times 50 \mathrm{~mm}$. Besides the model $A$, strengthening details under the rails of the seat of the frame with the shape of a triangular prism were modelled and this discrete model was marked as model B - Figure 1c. The generated midplane meshes with plate orthotropic finite elements have 5130 finite elements and 33616 DOF's for model $A$ and 5230 finite elements and 34096 DOF's for model $B$.

Linear static analyses by the Finite Elements Method (FEM) of the upholstered furniture frame models were carried out with CAE system Autodesk Simulation Mechanical ${ }^{\circledR}$.

Orthotropic materials for construction elements of the side frame for both models $A$ and $B$ were considered in the analyses:

Scots pine (Pinus sylvestris L.) for rails and strengthening details with measured density of $431 \mathrm{~kg} /$ $\mathrm{m}^{3}$ according to BDS EN 323:2001 and the following characteristics: $E_{\mathrm{z}}=E_{1}=9000 \times 10^{6} \mathrm{~N} / \mathrm{m}^{2}, E_{\mathrm{x}}=E_{\mathrm{t}}=593 \times 10^{6}$ $\mathrm{N} / \mathrm{m}^{2} ; \quad G_{\mathrm{lt}}=554.5 \times 10^{6} \mathrm{~N} / \mathrm{m}^{2} ; \quad v_{\mathrm{lr}}=0.03, \quad v_{\mathrm{lt}}=0.027$, $v_{\mathrm{tl}}=0.41, v_{\mathrm{rl}}=0.49$; bending strength $100 \times 10^{6} \mathrm{~N} / \mathrm{m}^{2}$; compression strength $\sigma_{c / /}=46 \times 10^{6} \mathrm{~N} / \mathrm{m}^{2}$ and $\sigma_{\mathrm{c} \perp}$ $=7.5 \times 10^{6} \mathrm{~N} / \mathrm{m}^{2}$; tension strength $\sigma_{\mathrm{t} / /}=109 \times 10^{6} \mathrm{~N} / \mathrm{m}^{2}$ and $\sigma_{\mathrm{t} \perp}=5.4 \times 10^{6} \mathrm{~N} / \mathrm{m}^{2}$; shear stress $7.4 \times 10^{6} \mathrm{~N} / \mathrm{m}^{2}$.

Particleboards (PB) for side plates with thickness of $16 \mathrm{~mm}$, measured density of $678 \mathrm{~kg} / \mathrm{m}^{3}$ and the following characteristics: modulus of elasticity in bend- 


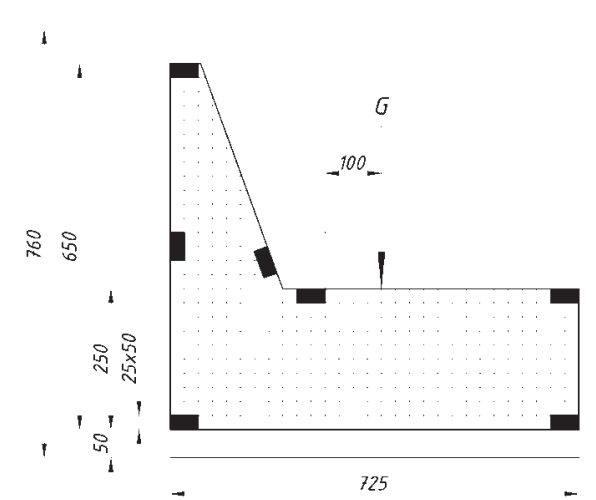

a)

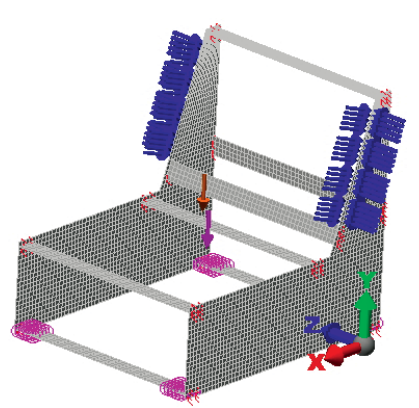

b)

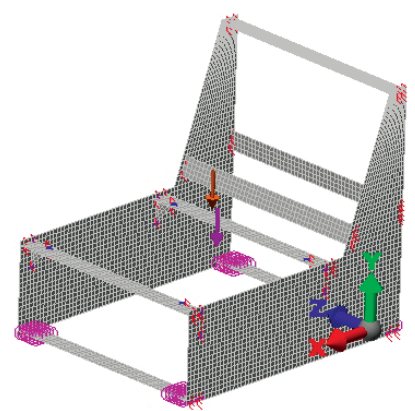

c)

Figure 1 FEM models A and B of upholstered furniture side frame and loading Slika 1. A i B modeli bočne stranice ojastučenog namještaja za FEM

ing $E_{\mathrm{y}}=E_{\perp}=2700 \times 10^{6} \mathrm{~N} / \mathrm{m}^{2}$ and $E_{\mathrm{x}}=E_{/ /}=1600 \times 10^{6} \mathrm{~N} /$ $\mathrm{m}^{2} ; \mathrm{v}_{\mathrm{yx}}^{\mathrm{y}}=0.30, \mathrm{v}_{\mathrm{xy}}=0.18$ (Bodig et al., 1982), bending strength $11 \times 10^{6} \mathrm{~N} / \mathrm{m}^{2}$; compression strength $\sigma_{\mathrm{c} / /}=13.4 \times 10^{6} \mathrm{~N} / \mathrm{m}^{2}$ and $\sigma_{\mathrm{c} \perp}=80 \times 10^{6} \mathrm{~N} / \mathrm{m}^{2}$; tension strength $\sigma_{\mathrm{t} / /}=7.9 \times 10^{6} \mathrm{~N} / \mathrm{m}^{2}$ and $\sigma_{\mathrm{t} \perp}=0.8 \times 10^{6} \mathrm{~N} / \mathrm{m}^{2}$; shear stress $6.1 \times 10^{6} \mathrm{~N} / \mathrm{m}^{2}$.

Oriented strandboard, type EGGER OSB2 with thickness of $16 \mathrm{~mm}$ (BDS EN 13986:2004) and the following mechanical characteristics: density $596 \mathrm{~kg} / \mathrm{m}^{3}$; modulus of elasticity in bending $E_{\mathrm{x}}=E_{/ /}=3800 \times 10^{6} \mathrm{~N} /$ $\mathrm{m}^{2}$; modulus of elasticity in bending $E_{\mathrm{y}}=E_{\perp}=3000 \times 10^{6}$ $\mathrm{N} / \mathrm{m}^{2}$; bending strength $\sigma_{\mathrm{m} / /}=16.4 \times 10^{6} \mathrm{~N} / \mathrm{m}^{2}$ and $\sigma_{\mathrm{m} \perp}=8.2 \times 10^{6} \mathrm{~N} / \mathrm{m}^{2}$; compression strength $\sigma_{\mathrm{c} / /}=15.4 \times 10^{6}$ $\mathrm{N} / \mathrm{m}^{2}$ and $\sigma_{c \perp}=12.7 \times 10^{6} \mathrm{~N} / \mathrm{m}^{2}$; tension strength $\sigma_{\mathrm{t} / /}=9.4 \times 10^{6} \mathrm{~N} / \mathrm{m}^{2}$ and $\sigma_{\mathrm{t} \perp}=7 \times 10^{6} \mathrm{~N} / \mathrm{m}^{2}$; shear stress $6.8 \times 10^{6} \mathrm{~N} / \mathrm{m}^{2} ; v_{\mathrm{xy}}=0.30$ (Thomas, 2003) and $v_{\mathrm{yx}}=0.24$, calculated by the equation (Bodig et al., 1982):

$$
\frac{v_{\mathrm{xy}}}{E_{\mathrm{x}}}=\frac{v_{\mathrm{yx}}}{E_{\mathrm{y}}},
$$

Plywood (PLY) boards from birch (Betula) with thickness of $15 \mathrm{~mm}$ and 11 layers (BDS EN 14279:2004) and the following characteristics: density of $629 \mathrm{~kg} / \mathrm{m}^{3}$; modulus of elasticity in bending $E_{\mathrm{x}}=E_{/ /}=7224 \times 10^{6} \mathrm{~N} /$ $\mathrm{m}^{2} ; \quad E_{\mathrm{y}}=E_{\perp}=5709 \times 10^{6} \mathrm{~N} / \mathrm{m}^{2} ; \quad$ bending strength $\sigma_{\mathrm{m} / /}=61 \times 10^{6} \mathrm{~N} / \mathrm{m}^{2}$ and $\sigma_{\mathrm{m} \perp}=57 \times 10^{6} \mathrm{~N} / \mathrm{m}^{2}$; compression strength $\sigma_{\mathrm{c} / /}=52.2 \times 10^{6} \mathrm{~N} / \mathrm{m}^{2}$ and $\sigma_{\mathrm{c} \perp}=52 \times 10^{6} \mathrm{~N} / \mathrm{m}^{2}$; tension strength $\sigma_{\mathrm{t} / /}=93 \times 10^{6} \mathrm{~N} / \mathrm{m}^{2}$ and $\sigma_{\mathrm{t} \perp}=54 \times 10^{6} \mathrm{~N} / \mathrm{m}^{2}$; shear stress $6 \times 10^{6} \mathrm{~N} / \mathrm{m}^{2} ; v_{\mathrm{xy}}=0.30$ (Bodig et.al., 1982) and $v_{\mathrm{yx}}=0.237$ (equation 1 ).

Support boundary conditions were set: bottom front rail - no translation on y direction, and bottom rear rail no translation on $x, y$ and $z$ direction - Figure $1 \mathrm{~b}$.

In order to simulate semi-rigid connections between rails and side plates of the frame, the following actions were performed: First - in the place of joints in the discrete frame model, narrow zones were created with established via tests by FEM lower modules of elasticity of the used materials; Second - the coefficients of rotational stiffness of the corner joints with 2 staples and PVAc glue, loading under compression were laboratory established by Hristodorova (2019) according to the method described in Jivkov et al. (2006): case butt joints (for pine-PB $c=1018 \mathrm{Nm} / \mathrm{rad}$; for pine-OSB $c=767 \mathrm{Nm} / \mathrm{rad}$; for pine-PLY $c=1788$
$\mathrm{Nm} / \mathrm{rad}$ ) and end to face butt joints (for pine-PB $c=$ $823 \mathrm{Nm} / \mathrm{rad}$; for pine-OSB $c=510 \mathrm{Nm} / \mathrm{rad}$; for pinePLY $c=1433 \mathrm{Nm} / \mathrm{rad}$ ). These coefficients of rotational stiffness were introduced in the nodes of the respective corner joints in the frame models as nodal 3D spring supports - Figure 1, b and c.

Both discrete frame models $A$ and $B$ were loaded with a total load of $800 \mathrm{~N}$, distributed as follows (Figure 1b): Seat: $80 \%$ was set as a remote force, distributed between rails of the seat with application point of $100 \mathrm{~mm}$ in front of the rear rail; Backrest: $16 \%$ set as equal nodal forces, distributed on the edges of the two sides of the backrest.

The validity of this approach was proven and described in Staneva et al. (2018a).

Additionally, both models $A$ and $B$ with side plates of PB, OSB and PLY, were loaded with a heavyservice load of $2400 \mathrm{~N}$, distributed only on the seat (Figure 1c) in order to calculate the failure indexes according to Tsai-Wu failure criteria:

$$
\begin{aligned}
F= & \left(\frac{1}{X_{\mathrm{t}}}-\frac{1}{X_{\mathrm{c}}}\right) \sigma_{1}+\left(\frac{1}{Y_{\mathrm{t}}}-\frac{1}{Y_{\mathrm{c}}}\right) \sigma_{2}+\frac{\sigma_{1}^{2}}{X_{\mathrm{t}} X_{\mathrm{c}}}+ \\
& +\frac{\sigma_{2}^{2}}{Y_{\mathrm{t}} Y_{\mathrm{c}}}+2 F_{12} \sigma_{1} \sigma_{2}+\frac{\tau_{12}^{2}}{S^{2}}
\end{aligned}
$$

Where

$\sigma_{1,} \sigma_{2}, \sigma_{12}$ and $\tau_{12}$ are the calculated normal and shear stresses;

$X_{\mathrm{t}}$ and $X_{\mathrm{c}}$ - longitudinal strength in both tension and compression;

$Y_{\mathrm{t}}$ and $Y_{\mathrm{c}}$ - transverse strength in both tension and compression;

$S$ - in-plane shear strength;

$F_{12}$ - interaction term.

Failure is predicted to occur when $F \geq 1$.

\section{RESULTS AND DISCUSSION}

3. REZULTATI I RASPRAVA

The main criteria for assessing the strength of the upholstered furniture frame, modelled with plate finite elements, are the extreme stresses (maximum principal stresses $\sigma_{\operatorname{maxPR}}$ and minimum principal stresses $\sigma_{\operatorname{minPR}}$ ) calculated for each structural element. The signs of the 
extreme stresses plus (+) and minus (-) are tension and compression stress, respectively.

The results of the static analysis for model $A$ and model $B$ of the upholstered furniture frame are shown in Table 1, Figure 2 to 10 . The previewing of deformed model in the figures is with a scale factor of $3 \%$ of model size for the whole model and $5 \%$ for side plates.

The maximum value of maximum principal stress $\sigma_{\text {maxPR }}$ (tension stress) $7.79 \times 10^{6} \mathrm{~N} / \mathrm{m}^{2}$ for the frame model $A$ with side plates of PB and $7.47 \times 10^{6} \mathrm{~N} /$ $\mathrm{m}^{2}$ for model with side plates of OSB is localized in the middle of the rear rail of the seat, on the bottom, while for the frame with side plates of PLY, it is localized in the side plate, in the area of attachment of rear rail of the seat $\left(7.63 \times 10^{6} \mathrm{~N} / \mathrm{m}^{2}\right)$, Table 1 . In the middle of the rear rail of the seat, on the bottom, the value of the tension stress $\left(\sigma_{\operatorname{maxPR}}\right)$ of the model with side plates of PLY is $6.94 \times 10^{6} \mathrm{~N} / \mathrm{m}^{2}$.

The maximum value (absolute) of the minimum principal stress $\sigma_{\operatorname{minPR}}$ (compression stress) of $-8.01 \times 10^{6}$ $\mathrm{N} / \mathrm{m}^{2}$ for model $A$ with side plates of PB is localized in the middle on the top of the rear rail of the seat (Figure 2 ), while for the frame with side plates of OSB and PLY, it is localized in the side plate, in the area of attachment of rear rail of the seat $\left(-11.78 \times 10^{6} \mathrm{~N} / \mathrm{m}^{2}\right.$ for OSB and $-12.88 \times 10^{6} \mathrm{~N} / \mathrm{m}^{2}$ for PLY) - Table 1 . In the middle of the rear rail of the seat, on the top, for model $A$ with side plates of OSB and PLY, the maximum value of the compression stress $\left(\sigma_{\operatorname{minPR}}\right)$ is $-7.78 \times 10^{6} \mathrm{~N} / \mathrm{m}^{2}$ for OSB and $-7.24 \times 10^{6} \mathrm{~N} / \mathrm{m}^{2}$ for PLY - Table 1 .

In model $B$, the localization of the maximum stress values is in the reinforcing details of rear rail of the seat for all materials of side plates (Figure 2 and 3, Table 1), due to the arising significant bending mo-
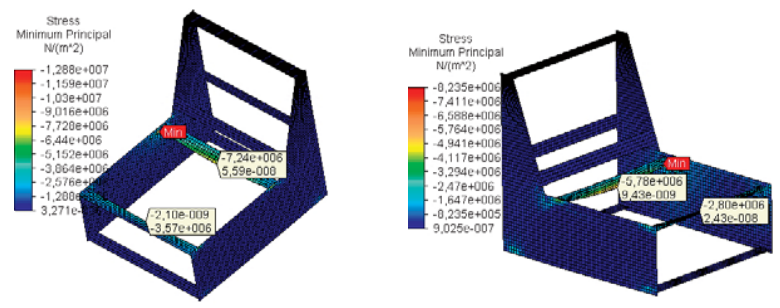

Figure 2 Distribution of $\sigma_{\operatorname{minPR}}$ for model $A$ and model $B$ with side plates of PLY

Slika 2. Raspodjela $\sigma_{\operatorname{minPR}}$ za model A i model B sa stranicama od furnirske ploče

ments in the joints with higher stiffness in the model. Due to the redistribution of the stresses, the reinforcement of the frame leads to decreasing of the maximum value of tension stress in the middle of the rear rail of the seat although insignificantly depending on the type of furniture boards: 1.2 times for the frame with PB side plates and 1.3 times for OSB and PLY side plates (Table 1), while the maximum value of compression stress decreases 1.2 times for all materials of the side plates (Figure 4, Table 1).

The reinforcement of the frame results in increasing of $\sigma_{\operatorname{maxPR}}$ in the joints of rear rail of the seat with the side plates 3 times for the frame with PB side plates and 1.1 time for the OSB side plates, while for PLY side plates it decreases 1.2 times (Table 1). The minimum principal stress in the joints of rear rail of the seat with the side plates increases 1.3 times for $\mathrm{PB}$ side plates, while it decreases for OSB side plates 1.4 times and for PLY side plates 1.6 times.

In the side plates for model $A$, the maximum value of tension stress $\left(\sigma_{\operatorname{maxPR}}\right)$ is localized at the front of

Table 1 Values of principal stresses in the model with side plates of PB, OSB and PLY

Tablica 1. Vrijednosti glavnih naprezanja u modelu s bočnim stranicama od iverice, OSB ploča i furnirskih ploča

\begin{tabular}{|c|c|c|c|c|c|c|c|}
\hline \multirow{2}{*}{$\begin{array}{l}\text { Parameter } \\
\text { Parametar }\end{array}$} & \multirow{2}{*}{ Location / Lokacija } & \multicolumn{2}{|c|}{$\begin{array}{c}\text { PB } \\
\text { Ploča iverica }\end{array}$} & \multicolumn{2}{|c|}{$\begin{array}{c}\text { OSB } \\
\text { OSB ploča }\end{array}$} & \multicolumn{2}{|c|}{$\begin{array}{c}\text { PLY } \\
\text { Furnirska ploča }\end{array}$} \\
\hline & & $\begin{array}{c}\text { model } \\
A\end{array}$ & $\begin{array}{c}\text { model } \\
B\end{array}$ & \begin{tabular}{c|c} 
model \\
$A$
\end{tabular} & $\begin{array}{c}\text { model } \\
B\end{array}$ & $\begin{array}{c}\text { model } \\
A\end{array}$ & $\underset{B}{\text { model }}$ \\
\hline \multirow{5}{*}{$\begin{array}{l}\sigma_{\operatorname{maxPR}} \times 10^{6} \mathrm{~N} / \mathrm{m}^{2} \\
(F=800 \mathrm{~N})\end{array}$} & front rail of the seat / prednji poveznik sjedala & 3.66 & 3.12 & 3.57 & 3.07 & 3.38 & 2.80 \\
\hline & rear rail of the seat / stražnji poveznik sjedala & 7.79 & 6.39 & 7.47 & 5.86 & 6.94 & 5.21 \\
\hline & rear rail - joint / stražnji poveznik - spoj & 4.63 & 4.16 & 5.39 & 4.53 & 6.19 & 5.04 \\
\hline & $\begin{array}{l}\text { side plate - joint rear rail } \\
\text { bočna stranica - spoj sa stražnjim poveznikom }\end{array}$ & 2.21 & 1.96 & 6.25 & 2.85 & 7.63 & 3.35 \\
\hline & $\begin{array}{l}\begin{array}{l}\text { strength. detail rear rail } \\
\text { pojačanje stražnjeg poveznika }\end{array} \\
\end{array}$ & - & 7.11 & - & 6.76 & - & 6.36 \\
\hline \multirow{5}{*}{$\begin{array}{l}\sigma_{\operatorname{minPR}} \times 10^{6} \mathrm{~N} / \mathrm{m}^{2} \\
(F=800 \mathrm{~N})\end{array}$} & front rail of the seat / prednji poveznik sjedala & -3.79 & -3.10 & -3.75 & -3.03 & -3.57 & -2.80 \\
\hline & rear rail of the seat / stražnji poveznik sjedala & -8.01 & -6.72 & -7.78 & -6.36 & -7.24 & -5.78 \\
\hline & rear rail - joint / stražnji poveznik - spoj & -4.15 & -3.95 & -4.94 & -4.32 & -5.95 & -4.71 \\
\hline & $\begin{array}{l}\text { side plate - joint rear rail } \\
\text { bočna stranica - spoj sa stražnjim poveznikom }\end{array}$ & -6.23 & -2.53 & -11.52 & -3.72 & -12.88 & -4.76 \\
\hline & $\begin{array}{l}\text { strength. detail rear rail } \\
\text { pojačanje stražnjeg poveznika }\end{array}$ & - & -8.29 & - & -8.27 & - & -8.24 \\
\hline \multirow{2}{*}{$\begin{array}{l}\sigma_{\operatorname{maxPR}} \times 10^{6} \mathrm{~N} / \mathrm{m}^{2} \\
(F=2400 \mathrm{~N})\end{array}$} & $\begin{array}{l}\text { side plate - front rail } \\
\text { bočna stranica - prednji poveznik }\end{array}$ & 11.48 & 8.30 & - & 10.69 & - & 12.40 \\
\hline & $\begin{array}{l}\text { side plate - rear rail } \\
\text { bočna stranica - stražnji poveznik }\end{array}$ & - & - & 22.05 & - & 28.47 & - \\
\hline $\begin{array}{l}\sigma_{\operatorname{minpR}} \times 10^{6} \mathrm{~N} / \mathrm{m}^{2} \\
(F=2400 \mathrm{~N})\end{array}$ & $\begin{array}{l}\text { side plate - rear rail } \\
\text { bočna stranica - stražnji poveznik }\end{array}$ & 23.47 & -9.46 & -37.21 & -14.10 & -48.40 & -12.87 \\
\hline
\end{tabular}



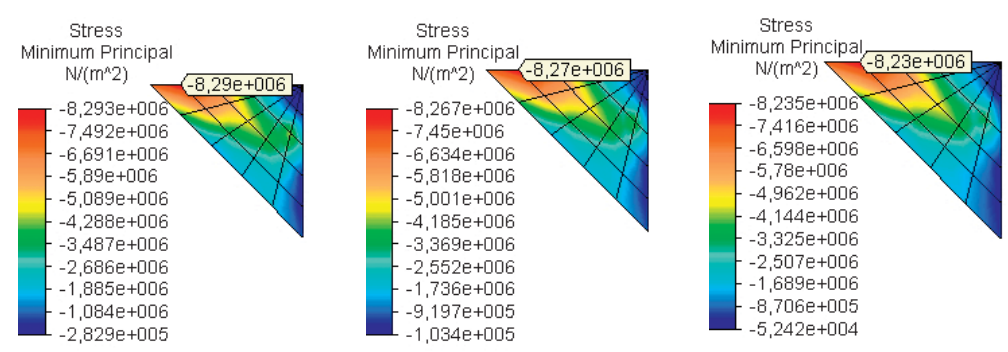

Figure 3 Distribution of $\sigma_{\text {minPR }}$ in reinforcing details (model B; PB, OSB and PLY side plates) Slika 3. Raspodjela $\sigma_{\operatorname{minPR}}$ za pojačane detalje (model B: iverica, OSB ploča, furnirska ploča)
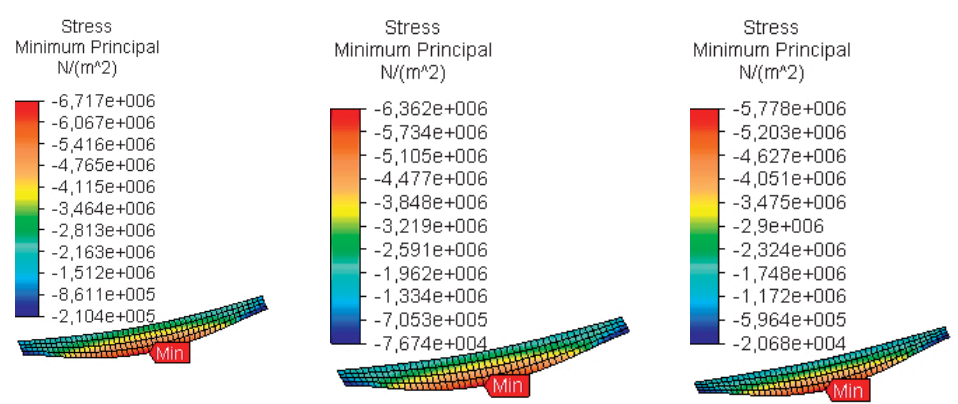

Figure 4 Distribution of $\sigma_{\text {minPR }}$ in rear rail of the seat (model B; PB, OSB and PLY side plates)

Slika 4. Raspodjela $\sigma_{\text {minPR }}$ za stražnji element sjedala (model B: iverica, OSB ploča, furnirska ploča)

the side plate, in the field of front rail of the seat for $\mathrm{PB}$ side plate, whereas for OSB and PLY side plate it is localized in the area of attachment of the rear rail of the seat - Figure 5. For the strengthened model $B$ for all materials, the maximum value of $\sigma_{\operatorname{maxPR}}$ in the side plate is localized at the front of the side plate, in the field of front rail of the seat due to the reinforcement of the seat rails - Figure 6.

For model $A$, the tension stress for PW side plate $\left(7.63 \times 10^{6} \mathrm{~N} / \mathrm{m}^{2}\right)$ is 2.5 times greater than that for PB $\left(3.05 \times 10^{6} \mathrm{~N} / \mathrm{m}^{2}\right)$ and 1.2 times than that for OSB $\left(6.25 \times 10^{6} \mathrm{~N} / \mathrm{m}^{2}\right)-$ Figure 5 . The tension stress for OSB side plate is 2 times greater than that for PB.
In model $B$, the tension stress for PW side plate $\left(3.55 \times 10^{6} \mathrm{~N} / \mathrm{m}^{2}\right)$ is 1.6 times greater than that for $\mathrm{PB}$ $\left(2.22 \times 10^{6} \mathrm{~N} / \mathrm{m}^{2}\right)$ and 1.2 times than that for OSB $\left(2.85 \times 10^{6} \mathrm{~N} / \mathrm{m}^{2}\right)-$ Figure 6 . The tension stress for OSB side plate is 1.3 greater than that for $\mathrm{PB}$.

The maximum value of the compression stress in the side plate is localized in the area of the rear seat rail attachment for all materials in model $A$ - Figure 7. For model $B$, for all materials, the maximum value of the compression stress in the side plate is also localized in the area of the rear seat rail attachment - for PB it is in the area of the reinforcing element, whereas for OSB and PLY it is at the top edging of the side plate - Figure
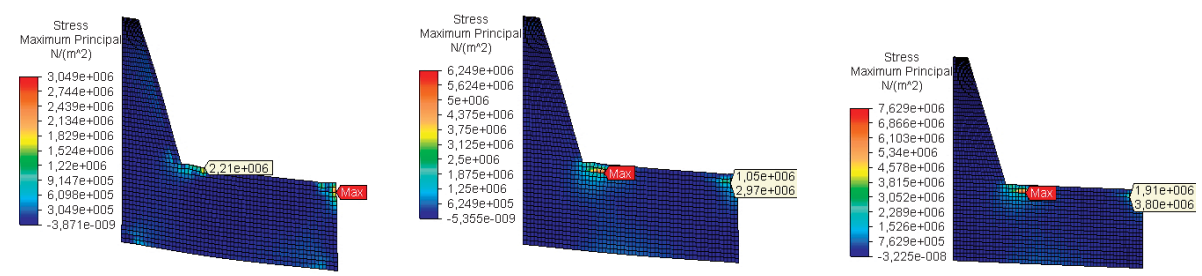

Figure 5 Distribution of max principal stress in side plates of PB, OSB and PLY for model A Slika 5. Raspodjela najvećih naprezanja u stranicama od iverice, OSB ploče i furnirske ploče za model A
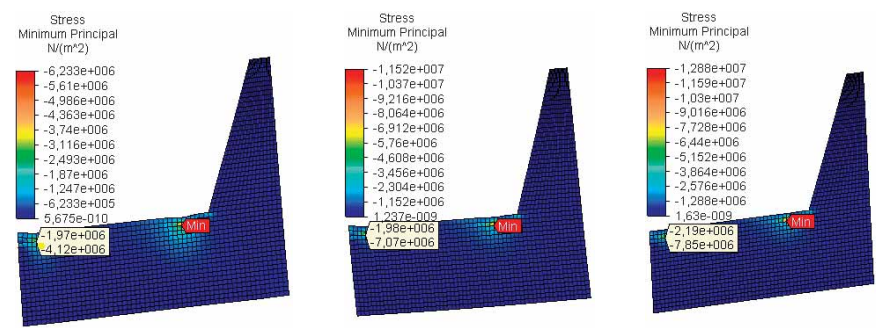

Figure 6 Distribution of min principal stress in side plates of PB, OSB and PLY for model A

Slika 6. Raspodjela najmanjih naprezanja u stranicama iverice, OSB ploče i furnirske ploče za model A 

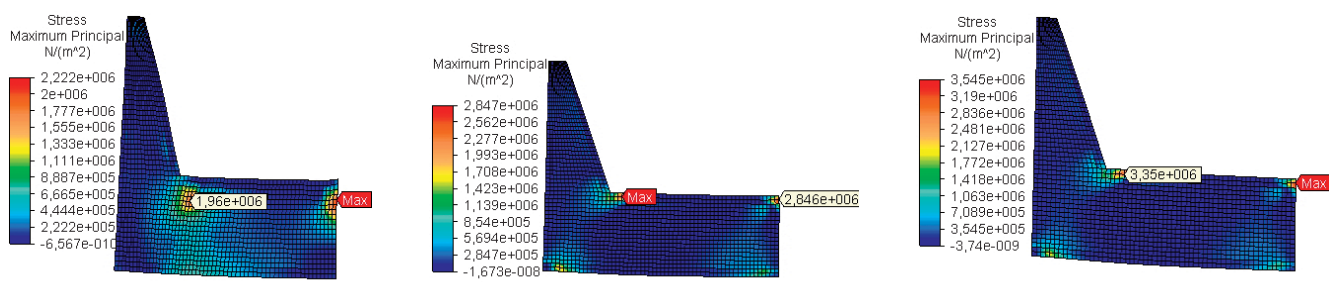

Figure 7 Distribution of max principal stress in side plates of PB, OSB and PLY for model $B$

Slika 7. Raspodjela najvećih naprezanja u stranicama od iverice, OSB ploče i furnirske ploče za model B
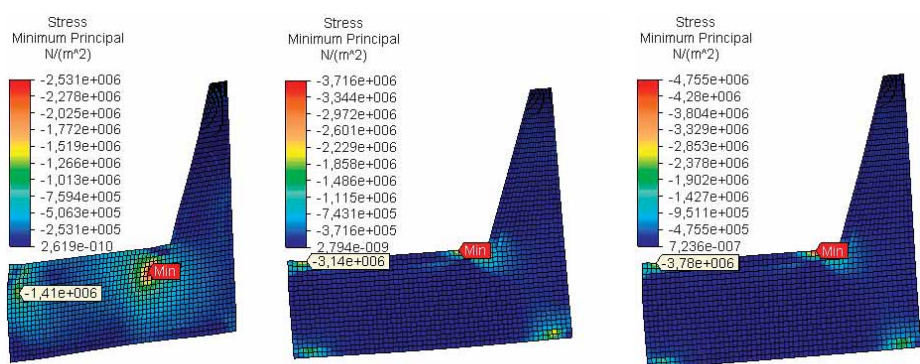

Figure 8 Distribution of min principal stress in side plates of PB, OSB and PLY for model $B$

Slika 8. Raspodjela najmanjih naprezanja u stranicama od iverice, OSB ploče i furnirske ploče za model B

8. The same phenomenon was found in the real tests of corner joints from Scots pine-OSB and Scots pine-PLY with two staples and glue (also established by Kasal (2006).

For model $A$, the absolute maximum value of the compression stress for PLY $\left(-12.88 \times 10^{6} \mathrm{~N} / \mathrm{m}^{2}\right)$ is 2.1 time greater than that for $\mathrm{PB}$ and 1.1 time than that for OSB - Figure 6. The compression stress for OSB $\left(-11.52 \times 10^{6} \mathrm{~N} / \mathrm{m}^{2}\right)$ is 1.85 times greater than that for PB. In model $B$, the compression stress for PLY $\left(-4.76 \times 10^{6} \mathrm{~N} / \mathrm{m}^{2}\right)$ is 1.9 times greater than that for $\mathrm{PB}$ and 1.3 times than that for OSB - Figure 8. The compression stress for OSB $\left(-3.72 \times 10^{6} \mathrm{~N} / \mathrm{m}^{2}\right)$ side plate is 1.5 times greater than that for PB.

The results for the principal stresses in heavyservice load $(F=2400 \mathrm{~N})$ indicate that the maximum values stresses, especially the minimum principal stresses in the side plates, have exceeded the strength of PB and OSB boards (Table 1).

In both models, the values of the in-plane failure index in the side plates in heavy-service load $(F=2400$ $\mathrm{N})$ only on the seat are greatest for side plates of PB, especially for model $A$ (Figure 9 and 10). The maximum value of the failure index is established in the field of the front rail joining to the side plate of $\mathrm{PB}$ for model $A$ and in the field of joining of strengthening details of rear rail for model $B$. Obviously, PB side plates have a high risk of damage in heavy-service load, even for the strengthened model $B$.

The failure index in side plates of OSB is also critical - $F>1$ for both models $A$ and $B$ and it is approximately 2 times lower than that for $\mathrm{PB}$ side plates.
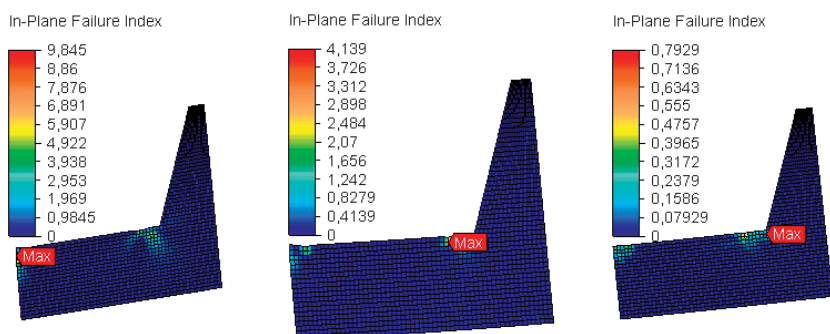

Figure 9 Failure index for PB, OSB and PLY side plates in model $A(F=2400 \mathrm{~N})$

Slika 9. Indeks loma stranica od iverice, OSB ploče i furnirske ploče za model A ( $F=2400 \mathrm{~N})$
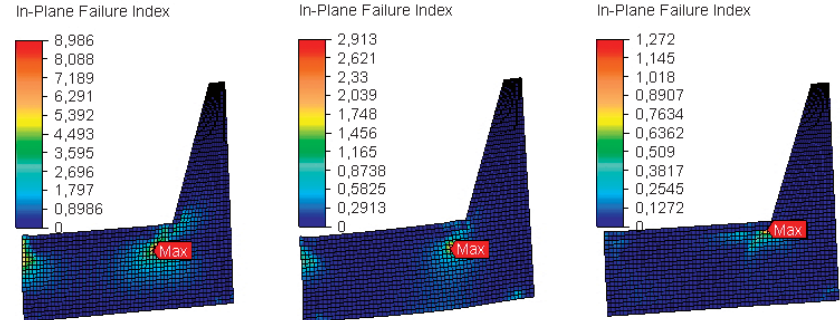

Figure 10 Failure index for PB, OSB and PLY side plates in model $B(F=2400 \mathrm{~N})$

Slika 10. Indeks loma stranica od iverice, OSB ploče i furnirske ploče za model B ( $F=2400 \mathrm{~N})$ 
For side plates of PLY, the failure index $F<1$ for model $A$ and approximately equal to 1 (1.27) for model $B$ (Figure 9 and 10).

\section{CONCLUSIONS}

\section{ZAKLJUČAK}

From the results of this study by FEM with CAE program Autodesk Simulation Mechanical ${ }^{\circledR}$ on the strength of the one-seat upholstered furniture frame with side plates of PB, OSB and PLY, rails of Scots pine and staples with glue corner joints under lightservice load, several conclusions can be derived:

1. Due to the redistribution of the stresses, the reinforcement of the seat rails improves the strength of the upholstered furniture frame: the maximum values of the tension stresses decrease by about $8.7 \%$ for the frame with side plates of $\mathrm{PB}, 9.5 \%$ for OSB and $17 \%$ for PLY; compression stresses decrease by about $28 \%$ for the frame with side plates of OSB and $36 \%$ for PLY, while for PB side plates, they increase by $3 \%$ almost negligible.

2. The most critical joints in the investigated upholstered furniture frame are the joints of rear rail of the seat with the side plates for all side plate materials. The reinforcement of the frame results in increasing the compression stress in these joints by $33 \%$ for PB side plates and decreasing by $28 \%$ for OSB and $36 \%$ for PLY side plates.

3. The strength behaviour of the side plates of PB, OSB and PLY is considerably improved after strengthening of the rails to the side plate joints of the seat: the tension stresses in the side plates are reduced by approximately $27 \%$ for PB, $54 \%$ for OSB and PLY. The compression stresses are reduced by approximately $59 \%$ for PB, $68 \%$ for OSB and $63 \%$ for PLY.

4. The type of furniture plate affects the strength of the side plates in the upholstered furniture frame: in the reinforced frame the tension stress decreases by approximately $38 \%$ for side plates of PB and $20 \%$ for side plates of OSB and PLY; the compression stress decreases by approximately $47 \%$ for side plates of PB and $22 \%$ for side plates of OSB and PLY.

5. All results for stresses and failure indexes determine PLY side plates as the most appropriate and PB side plates as the most inappropriate furniture boards for upholstered side frame constructions concerning their strength. In order to observe safety requirements in designing, frames with side plates of PB and OSB in case of joints with staples and glue have to be produced of boards with thickness of $18 \mathrm{~mm}$ or to be further strengthened.

6. The values obtained for the maximum and minimum principal stresses allow the prediction of strength behaviour of upholstered furniture frame made of Scots pine rails and side plates of PB, OSP and PLY and corner joints with staples and glue.

\section{REFERENCES}

\section{LITERATURA}

1. Bodig, J.; Jayne, B., 1982: Mechanics of wood and wood composites. New York, Van Nostrand Reinhold Co. Inc.

2. Erdil, Y.; Kasal, A.; Eckelman, C., 2008: Theoretical Analysis and Design of Joints in a Representative Sofa Frame Constructed of Plywood and Oriented Strand Board. Forest Products J., 58 (7/8): 62-67.

3. Hristodorova, D., 2019: Stiffness coefficients in joints by staples of skeleton upholstered furniture. J. Innovation in Woodworking Industry and Engineering Design (INNO), 2.

4. Kasal, A., 2006: Determination of the Strength of Various Sofa Frames with Finite Element Analysis, G. U. Journal of Science, 19 (4): 191-203.

5. Marinova, A., 1996: Methodology of stress and strain furniture structure analysis, Proceeding of Intern. Sci. Conference «Mechanical Technology of Wood», Sofia, pp. 257-267.

6. Smardzewski, J., 2001: Construction Optimisation of Upholstred Furniture. Folia Forestalia Polonica, Seria B, 32: 5-19.

7. Smardzewski, J.; Prekrat, S., 2009: Optimisation of a sofa frame in the integrated CAD-CAE environment. Electronic J. of Polish Agricultural Universities (Wood Technology), 12 (4): 9. http://www.ejpau.media.pl/

8. Staneva, N.; Genchev, Ya.; Hristodorova, D., 2018a: Approach for design of an upholstered furniture frame by the Method of Finite Elements. Acta Facultatis Xylologiae Zvolen, 60, (2): 61-69. https://doi.org/10.7546/crabs.2018.10.12.

9. Staneva, N.; Hristodorova, D.; Genchev, Ya.; Zarkin, Y., 2018b: FEA of stresses of an upholstered furniture skeleton with side plates from OSB. Sci. Journal Chip and Chipless Woodworking Processes, 11 (1): 171-176.

10. Staneva, N.; Genchev, Ya.; Hristodorova, D., 2018c: FEM analysis of deformation and stresses of upholstered furniture skeleton made of Pinus Sylvestris and Plywood. Sci. Journal Management and Sustainable Development, 69 (2): 56-61.

11. Thomas, W., 2003: Poisson's Ratio of an Oriented Strand Board. Wood Sci. Tehnology, 37 (3): 259-268. https://doi.org/10.1007/s00226-003-0171-y.

12. Wang, X., 2007: Designing, Modeling and Testing of Joints and Attachment Systems for the Use of OSB in Upholstered Furniture Frames. PhD thesis. University Laval, Quebec, Canada.

13. *** Autodesk, 2015: Simulation Mechanical ${ }^{\circledR}$, Online User's Guide \& Help Files.

\section{Corresponding address:}

Assist. Prof. Ing. NELLY STANEVA, PhD

University of Forestry

Faculty of Forest Industry

Department of Furniture Production

1797 Sofia, BULGARIA

e-mail: nelly_staneva@yahoo.com 